\title{
HILANGNYA KEADILAN DALAM PENEGAKAN HUKUM MENURUT TEORI DISKRIMINASI
}

\author{
Nurindria Naharista Vidyapramatya \\ Universitas Sebelas Maret \\ E-mail: atyanaharistav@gmail.com
}

\begin{abstract}
The Indonesian nation is currently experiencing a crisis of justice in law enforcement. This happens because it is only concerned with the aspects of legal certainty and formal-legality rather than justice. The law cannot be enforced if there are no credible, competent and independent law enforcement officers. Legal discrimination is a way for law enforcement officials to differentiate in the imposition of sanctions against someone who is influenced by that person's ability both in the economic and power fields. This study discusses how discriminatory law enforcement is when viewed from Donald Black's theory. The author will compare two cases with the same type of crime but different decisions. Then studied through Donald Black's theory of legal discrimination. The purpose of this study was to determine the existence of discrimination in law enforcement from two similar cases but with different decisions which were reviewed through Donald Black's theory of legal discrimination. The research method used by the author in this study is a normative juridical research method. The preparation of this research is analytical descriptive with a conceptual approach. The conceptual approach needs to examine legal principles that can be found from the perspective of scholars or legal doctrine. The results of this research are indeed proven that there is legal discrimination that occurs, this can be seen from the study of Donald Black's theory. The suggestion for law enforcers is to be fair in any case, do not favoritism and discriminate, because all citizens are the same, equally need justice.
\end{abstract}

Keywords: Justice, Law Enforcement, Discrimination

\begin{abstract}
Abstrak
Bangsa Indonesia saat ini sedang mengalami krisis keadilan dalam penegakan hukum. Hal ini terjadi karena semata-mata hanya mementingkan aspek kepastian hukum dan legalitas-formal daripada keadilan. Hukum tidak dapat ditegakkan apabila tidak ada aparat penegak hukum yang berkredibilitas, berkompeten dan independen. Diskriminasi hukum merupakan cara aparat penegak hukum yang membedakan dalam pemberian sanksi terhadap seseorang yang dipengaruhi oleh kemampuan orang tersebut baik dalam bidang ekonomi maupun kekuasaan. Penelitian ini membahas tentang bagaimana diskriminasi penegakan hukum jika ditinjau dari teori milik Donald Black. Penulis akan membandingkan dua kasus dengan jenis tindak pidana yang sama namun putusan yang berbeda. Lalu dikaji melalui teori diskriminasi hukum milik Donald Black. Tujuan dari penelitian ini adalah untuk mengetahui adanya diskriminsi dalam penegakan hukum dari dua kasus yang serupa tetapi memiliki putusan yang berbeda yang ditinjau melalui teori diskriminasi hukum milik Donald Black. Metode penelitian yang digunakan penulis dalam penelitian ini adalah metode penelitian yuridis normatif. Penyusunan penelitian ini bersifat diskriptif analitis dengan pendekatan konseptual. Pendekatan konseptual perlu mengkaji prinsip-prinsip hukum yang dapat ditemukan dari pandangan sarjana ataupun doktrin hukum. Hasil dari penelitian ini memang terbukti adanya diskriminsinasi hukum yang
\end{abstract}


terjadi, hal ini dapat dilihat dari kajian teori Donald Black. Saran bagi para penegak hukum adalah bersikap adil terhadap kasus apapun jangan pilih kasih dan membeda-bedakan, karena semua warga negara adalah sama, sama sama butuh keadilan.

Kata Kunci : Keadilan, Penegakan Hukum, Diskriminasi

\section{A. Pendahuluan}

Keberhasilan suatu negara dapat dilihat dari cara mereka mengangkat harkat martabat di bidang hukum terutama di dalam memberikan perlindungan hukum terhadap masyarakatnya bisa dilihat dari sudah baik dan efektif dalam menjalankan penegakan hukum.

Bangsa Indonesia saat ini sedang mengalami krisis keadilan dalam penegakan hukum. Hal ini terjadi karena semata-mata hanya mementingkan aspek kepastian hukum dan legalitas-formal daripada keadilan. Adagium hukum berupa keadilan (justice) tidak lagi berada pada hakikatnya, karena suatu peraturan perundang-undangan harus adil dalam pengimplementasiannya, namun dalam kenyataannya adalah adanya ketidakadilan (injustice).

Keadilan merupakan keinginan yang harus terpenuhi dalam menegakkan hukum. Keadilan memiliki sifat individualis serta tidak menyamaratakan. Jika penegak hukum memegang teguh pada nilai keadilan namun nilai kemanfaatan serta kepastian hukum tidak diperhatikan, maka hukum tidak akan berjalan dengan mulus. Lalu jika menitik beratkan pada nilai kemanfaatan tetapi mengesampingkan kepastian hukum dan keadilan maka hukum tidak akan berjalan. Seharusnya jika ingin menegakkan hukum, nilai keadilan, kemanfaatan dan kepastian hukum harus seimbang dan selaras. ${ }^{1}$

Hukum dapat ditegakkan apabila memiliki aparat penegak hukum yang berkredibilitas, berkompeten dan mandiri. Sebagus-bagusnya suatu hukum apabila tidak didukung dengan adanya aparat penegak hukum yang baik maka tidak akan tercipta suatu keadilan.

Kekuasaan lembaga penegak hukum diatur di dalam undang-undang. Maka dalam melakukan tugas dan tanggung jawabnya tidak terpengaruh oleh kewenangan pemerintah atau pengaruh dari luar.

Masalah yang krusial dalam penegakan hukum bukan sekedar terhadap produk hukum yang tidak kooperatif tetapi juga karena dari aparat penegak hukumnya. Pilar utama dalam penegakan hukum adalah para aparat penegak hukum yang melaksanakan tugasnya dengan integritas serta dedikasi yang baik.

Masyarakat selalu menginginkan adanya kepastian hukum, karena dengan adanya kepastian hukum maka kehidupan dalam masyarat akan damai. Apabila masyarakat menginginkan manfaat dalam praktek penegakan hukum, maka keadilan adalah hal yang paling utama diperhatikan. Karena kehidupan masyarakat diciptakan agar harmonis dan teratur. Tetapi dalam kenyataannya hukum yang dibuat tidak memuat keseluruhan masalah yang ada di masyarakat. Pada struktur kenegaraan tugas penegak hukum dilakukan oleh komponen eksekutif dan dilaksanakan oleh birokrasi eksekutif atau yang biasa disebut dengan birokrasi penegak hukum. Keikutsertaan hukum semakin aktif semenjak negara

1 Hasaziduhu Moho, "Penegakan Hukum di Indonesia Menurut Aspek Kepastian Hukum, Keadilan, dan Kemanfaatan" Jurnal Warta, Edisi 59 (2019) 
ikut dalam menangani banyak aktivitas dan pelayanan masyarakat, Contohnya pada bidang kesehatan, sosial, budaya, dan pendidikan. ${ }^{2}$

Jimly Asshiddiqie menjelaskan bahwa penegakan hukum merupakan proses melakukan cara agar berjalan atau berfungsinya norma hukum secara konkret sebagai penuntun kehidupan dalam berperilaku atau hubungan hukum dalam kehidupan masyarakat. ${ }^{3}$

Fenomena hilangnya keadilan dalam penegakan hukum terjadi karena lemahnya pemahaman agama, ekonomi serta empati para aparat penegak hukum. Hukum cenderung dijadikan sebagai sarana untuk mewujudkan kepentingan-kepentingan penguasa negara.

Menurut Satjipto Rahardjo, melihat penegakan hukum dalam suatu negara dari prosesnya yang aktif dan yang diperlihatkan di depan masyarakat adalah hasil penegakan hukum itu tidak dapat diterima sebagai karya penegak hukum tetapi hasil dari cara saling mempengaruhi di antara bagian-bagian yang terlibat. ${ }^{4}$

Penegakan hukum serta keadilan di Indonesia masih belum jelas, hal ini bisa dilihat dari sistem hukum, struktur, serta budaya yang masih berantakan. Hukum di Indonesia kurang berpihak kepada kepentingan masyarakat, adanya tebang pilih dan dikuasai oleh para orang-orang yang memiliki kekuasaan. ${ }^{5}$

Masalah penegakan hukum di Indonesia sangatlah banyak, mulai dari masyarat yang hanya mencari kesuksesan bukan keadilan. Warga yang menempati di kota besar yang biasanya terlibat dalam masalah hukum selalu berupaya agar terhindar dari hukuman, segala cara dilakukan agar semata-mata hanya ingin mendapatkan kemenangan. Hal ini berarti diindikasikan bahwa keadilan bagi mereka adalah hanya sebuah kemenangan. Masyarakat yang hanya ingin mendapatkan kemenangan menjadikan ini masalah bagi para penegak hukum yang kurang berkredibilitas dan rawan untuk di suap, warga yang mencari kesuksesan ini hanya mengandalkan kekuasaan dan materi mereka supaya tidak terkena hukuman. ${ }^{6}$

Masalah selanjutnya adalah adanya uang yang mewarnai penegakan hukum. Para aparat penegak hukum ini rentan untuk melakukan praktik korupsi dan menerima suap. Dengan uang pasal yang akan didakwakan bisa saja berubah tergantung jumlah uang yang ditawarkan agar mendapatkan hukuman yang serendah-rendahnya dan seringan mungkin. Bagi masyarakat yang memiliki uang akan diperlakukan baik selama proses hukum berlangsung. ${ }^{7}$

Penegakan hukum yang diskriminatif adalah penegakan hukum yang berpihak kepada orang yang memiliki kekuasaan dan materi bukan pada orang yang tidak memiliki kekuasaan dan materi, bahkan hukum akan berpihak kepada mereka yang memiliki kekuasaan,

2 Laurensius Arliman S., "Mewujudkan Penegakan Hukum yang baik di Negara Hukum Indoesia” Dialogia Iuridica, Vol. 11 No. 1 (2019): 010-020

3 Hasaziduhu Moho, "Penegakan Hukum di Indonesia Menurut Aspek Kepastian Hukum, Keadilan, dan Kemanfaatan" Jurnal Warta, Edisi 59 (2019)

4 Satjipto Rahardjo dan Anton Tabah. Polisi, Pelaku dan Pemikir. (Jakarta: Gramedia Pustaka Utama., 1993) hlm. 146

5 Umar Sholahudin, "Membangun Keadilan Restoratif Bagi Si Miskin”, Sejarah Dan Budaya, Tahun Ketujuh, No. 1, (2013): 34-50, hlm.34

6 Zainab Ompu Jainah, "Penegakan Hukum dalam Masyarakat", Journal of Rural and Development, Vol. 3 No. 2 (2012) 165-172, hlm. 170

$7 \quad$ Ibid. 170 
pangkat, atau hubungan dengan pejabat hukum atau aparat penegak hukum. Hal ini terjadi karena mentalitas penegak hukum yang hanya memandang masyarakat dari kedudukan sosialnya bukan dari apa yang dilakukan orang tersebut dalam proses hukum. ${ }^{8}$

Abdul Mukthie Fadjar menjelaskan ada empat unsur yang mempengaruhi penegakan hukum pelayanan publik agar tercapainya kepastian, keadilan, dan kemanfaatan, yaitu:

1. Faktor substansial fakta hukumnya;

2. Faktor struktural, yakni aparat penegak hukumnya;

3. Faktor kultural, yaitu kewaspadaan hukum para yustiabel;

4. Faktor manajerial yaitu administrasi organisasi pengelolaannya. ${ }^{9}$

Hukum dibentuk dengan tujuan untuk memberikan keadilan dan menciptakan kehidupan yang aman dan tertib bagi masyarakat. Politik kekuasaan dan ekonomi merupakan faktor yang membuat rakyat kecil sulit untuk mendapatkan keadilan. Dengan terciptanya ketertiban dan keseimbangan di dalam kehidupan, yang diinginkan supaya kepentingan manusia akan terpenuhi. Untuk mewujudkan tujuan dari hukum itu sendiri, hukum memiliki wewenang untuk membagi hak dan kewajiban antar manusia dalam kehidupan, membagi tugas dan mengatur cara mengatasi masalah hukum serta memperjuangkan kepastian hukum.

Untuk meningkatkan usaha dalam melakukan penegakan hukum yang baik terhadap warga negara maupun aparatur penegak hukum, maka pemerintah Indonesia sudah melaksanakan pembaharuan pada beberapa peraturan untuk mengubah sistem hukum yang ada untuk terwujudnya masyarakat yang tertib dan damai. Adanya perubahan peraturan untuk aparat penegak hukum diharapkan dapat melakukan tugas, fungsi, dan wewenangnya dengan semestinya karena pelaksaan tersebut akan mendapatkan pengawasan oleh pemerintah dan masyarakat.

Teori keadilan menurut John Rawls, ada tiga macam kebenaran, dua diantaranya adalah nilai moral yang sangat dipantau dan yang ketiga adalah interpretasi yang ada kaitannya terhadap teorinya.

Pandangan John Rawls tentang asas-asas keadilan yang utama adalah adanya asas persamaan, yaitu setiap orang yang sama atas kebebasan bersifat global, fundamental dan harmonis serta ketidaksamaan dalam kebutuhan sosial dan finansial. ${ }^{10}$

Menurut Aristoteles pandangannya mengenai keadilan adalah sebagai suatu pemberian persamaan hak. Hak persamaan ini dibedakan sesuai dengan hak proporsionalnya. Ada dua jenis keadilan, yaitu keadilan distributief dan commutatief.

Keadilan distributief adalah keadilan yang memberikan tiap individu sesuai dengan porsi menurut prestasinya. Sedangkan keadilan commutatief adalah keadilan yang memberikan sama banyaknya terhadap setiap individu tanpa memilah-milah prestasinya. ${ }^{11}$

$8 \quad$ Ibid. 171

9 Asep H. Suparman, "Penegakan Hukum terhadap Penyelenggaraan Publik" Jurnal Wawasan Yuridika, Vol. 29 No. 2 (2013): 849-853, hlm. 851

10 Ana Suheri, “Wujud Keadilan dalam Masyarakat di Tinjau dari Perspektif Hukum Nasional”, Jurnal Morality, Vol. 4 No. 1 (2018): 60-68, hlm. 63

11 Ibid. 62 
Hambatan yang akan ditemui pada peranan yang selayaknya dari penegak hukum dalam menerapkan hukum menurut Soerjono Soekanto adalah:

1. Dependensi kemampuan untuk menempatkan diri dalam peranan pihak lain dengan siapa dia interaksi

2. Tingkat aspirasi yang relatif belum tinggi

3. Keinginan yang sangat sempit untuk memikirkan masa depan, sehingga sulit sekali untuk membuat proyeksi

4. Belum adanya kekuatan untuk menunda pemuasan serta kebutuhan tertentu, terutama kebutuhan materiil

5. Kurangnya usaha inovatif yang sebenarnya merupakan pasangan konservatisme.

Penegakan hukum adalah usaha yang dilakukan untuk membuat hukum lebih baik, sebagai petunjuk perilaku manusia dalam setiap perilaku hukum. Baik oleh individu yang bersangkutan secara langsung atau aparat penegak hukum yang legal yang telah diberikan kekuasaan oleh undang-undang yang befungsi untuk melindungi dan menanggung prinsipprinsip hukum yang berlaku dalam kehidupan bersama.

Penegakan hukum di Indonesia masih belum berlangsung dengan baik. Adanya masalah ini selalu terjadi karena adanya ketidak selarasan hubungan yang dinamis antara faktor hukum das sollen dengan faktor penerapan hukum dalam kenyataan das sein. Kurang optimalnya penegakan hukum di negara ini tercemin dari beberapa penyelesaian kasus besar yang belum selesai, contohnya adalah kasus korupsi. ${ }^{12}$

Berbeda apabila kasus yang melibatkan rakyat kecil maka para penegak hukum akan melukai hati rakyat kecil yang akhirnya membuat rakyat memiliki rasa ketidakpercayaan lagi kepada aparat penegak hukum. Aparat penegak hukum rentan untuk melakukan praktik suap, maka membuat hukum di negeri ini nyata bisa diperjual belikan. ${ }^{13}$

Hilangnya keadilan dalam penegakan hukum menyebabkan munculnya rasa sulit untuk percaya terhadap aparat penegak hukum bagi masyarakat. Penurunan kepercayaan menyebabkan terjadinya diskriminasi yang dialami oleh aparat penegak hukum dalam kehidupannya. Banyak warga yang terkesan menjaga jarak dengan aparat penegak hukum, hal ini merupakan dampak negatif dari prasangka yang muncul dari warga negara terhadap aparat penegak hukum dalam menjalankan proses penegakan hukum. ${ }^{14}$

Diskriminasi adalah wujud pembatasan, pelecehan, atau pengucilan baik secara langsung atau tidak langsung yang berlandaskan pada adanya keberagaman agama, suku, ras, etnik, golongan, status sosial, status ekonomi, gender, bahasa, serta keyakinan politik yang mengakibatkan adanya pengurangan, penyimpangan, atau penghapusan pengakuan, pelaksanaan atau penggunaan hak asasi manusia yang dilakukan secara individu maupun kolektif dalam bidang politik, ekonomi, hukum, sosial, budaya, dan bidang kehidupan lainnya. ${ }^{15}$

12 Ucuk Agiyanto, "Penegakan Hukum di Indonesia: Eksplorasi Konsep Keadilan Berdimensi Ketuhanan" Hukum Ransendental, 493-503, hlm.494

13 Ibid

14 Ismail Shaleh Rusli, "Prasangka Menimbulkan Penurunan Tingkat Kepercayaan Masyarakat Terhadap Penegak Hukum", Indonesia yang Berkeadilan Sosial tanpa Diskriminasi, (2016): 239-245, hlm. 244

15 Undang-Undang Republik Indonesia Nomor 39 Tahun 1999 tentang Hak Asasi Manusia 
Dalam menciptakan kehidupan yang tertib, tentram, serta aman maka diperlukannya aturan hukum untuk menjaga kehidupan sosial supaya setiap individu bisa berkelakuan baik. Tetapi dengan adanya perelisihan antar manusia memanglah sering terjadi, maka hukum diberlakukan untuk siapa pun yang melakukan perbuatan melanggar hukum.

Peradilan merupakan salah satu institusi penegak hukum yang kegiatannya tidak jauh dari hukum yang telah dibuat dan disuguhkan oleh badan pembuat hukum. Maka dari itu adanya perbedaan peradilan dan pengadilan dalam proses penegakan hukum.

Penegakan hukum sangat mudah dihasut oleh keadaan dan hubungan sosial yang ada di kehidupan, dapat dituliskan dalam masyarakat yang merawat atau mengembangkan sistem hak-hak dasar atas status, atau suatu masyarakat yang ada di dalam kawasan kekuasaan yang otoriter, yang akan memposisikan sistem penegakan hukum yang berbeda dengan masyarakat yang open. Penegakan hukum yang baik dan adil ditentukan oleh partisipasi masyarakat, bukan hanya keinginan aparat penegak hukum.

Diskriminasi hukum merupakan cara aparat penegak hukum yang membedakan dalam pemberian sanksi terhadap seseorang yang dipengaruhi oleh kemampuan orang tersebut baik dalam bidang ekonomi maupun kekuasaan. Jadi diskriminasi hukum adalah adanya ketidak adilan penegak hukum dalam menegakkan hukum.

Terjadinya diskriminasi hukum di Indonesia karena kurang tegasnya hukum yang ada, sehingga seseorang yang memiliki kekuasaan serta kemampuan ekonomi berusaha untuk "membeli" hukum agar terbebas dari hukuman. Berbeda dengan masyarakat yang tidak memiliki kekuasaan dan ekonomi, mereka tidak bisa membela diri dan menerima sanksi atas perbuatan melanggar hukum.

Munculnya stigma "hukum tumpul ke atas dan tajam ke bawah" memanglah benar adanya. Hal ini akan penulis buktikan dalam penelitian ini yaitu bagaimana diskriminasi penegakan hukum jika ditinjau dengan teori milik Donald Black. Penulis akan membandingkan dua kasus dengan jenis tindak pidana yang sama namun putusan yang berbeda. Lalu dikaji melalui teori diskriminasi hukum milik Donald Black. Penelitian ini bertujuan untuk mengetahui adanya diskriminsi dalam penegakan hukum dari dua kasus yang serupa tetapi memiliki putusan yang berbeda yang ditinjau melalui teori diskriminasi hukum milik Donald Black. Penulis dalam penelitian ini menggunakan metode penelitian yuridis normatif. Penyusunan penelitian ini bersifat diskriptif analitis dengan pendekatan konseptual. Pendekatan konseptual harus mengkaji asas-asas hukum yang didapati dari pandangan sarjana ataupun doktrin hukum. ${ }^{16}$

\section{B. Pembahasan}

\section{Kasus Diskriminasi Hukum}

Pada tanggal 1 Januari 2013 adanya berita peristiwa kecelakaan yaitu anak bungsu Menteri Koordinatir Perekonomian Hatta Rajasa menabrak satu kendaran roda empat di ruas jalan Tol Jagorawi Jakarta Timur.

Kronologi kejadiannya yaitu pada pukul 05.30 WIB, terdakwa M. Rasyid Amrullah Rajasa bersama temannya Prilla Kinanti pergi dari rumah Prilla di daerah Tebet, Jakarta

16 Peter M. Marzuki, Penelitian Hukum. (Jakarta: Prenadamedia Group, 2005) 
Selatan yang akan pulang ke rumah terdakwa di daerah Cilandak Barat, Jakarta dengan menggunakan kendaraan mobil Jeeep BMW dengan Nomor polisi B 272 HR.

Ketika sampai di Cawang Interchange terdakwa membelokkan kendaraannya ke arah kanan masuk Jalan Tol dalam kota ke arah selatan, pada saat itu keadaan lalu lintas sepi lancar dan cuaca juga cerah. M. Rasyid Amrullah Rajasa mengemudikan kendaraanya di jalur cepat dengan kecepatan sekitar 100 km/jam, sedangkan kecepatan yang diperbolehkan di jalan tol kota Jakarta Timur arah selatan jalur kanan maksimum $80 \mathrm{~km} / \mathrm{jam}$ dan minimum $60 \mathrm{~km} / \mathrm{jam}$ dan terdakwa mengemudikan mobil dalam keadaan belum tidur semalaman karena baru saja merayakan malam tahun baru.

Terdakwa yang tidak hati-hati dan melihat keberadaan kendaraan lain didepannya mengakibatkan kendaraan Jeep BMW menabrak dengan kencang kendaraan Daihatsu Luxio dengan Nomor Polisi F 1622 CY. Akibatnya, kendaraan Daihatsu Luxio yang dikemudikan oleh Frans Jonar Sirait yang melaju dengan kecepatan sekitar $70 \mathrm{~km} /$ jam, mengakibatkan pintu belakang mobil terbuka dan para penumpang yang duduk di belakang terlempar dan jatuh ke aspal. Para korban tersebut adalah Enung, Supriyati, Ripal Mandala Putra, Harun, M. Raihan. Korban meninggal adalah Harun dan M. Raihan sedangkan lainnya mengalami luka-luka.

M. Rasyid Amrullah Rajasa dibawa secara hukum dan didakwa melakukan tindak pidana karena kelalaiannya mengakibatkan kecelakaan lalu lintas dengan korban luka berat dan korban meninggal dunia. Sesuai dengan dakwaan kesatu, Primair Pasal 310 ayat (4) Undang-Undang No. 22 Tahun 2009 tentang Lalu Lintas dan Angkutan Jalan, serta terbukti bersalah melakukan tindak pidana karena kelalaiannya mengakibatkan kecelakaan lalu lintas dengan korban luka ringan dan kerusakan kendaraan dan/atau barang sesuai dengan dakwaan Pasal 310 ayat (2) Undang-Undang No. 22 Tahun 2009 tentang Lalu Lintas dan Angkutan Jalan.

M. Rasyid Amrullah Rajasa dituntut dengan pidana penjara selama 8 (delapan) bulan dengan masa percobaan selama 12 (dua belas) bulan dan denda sebesar Rp. 12.000.000,- (dua belas juta rupiah) subsidair selama 6 (enam) bulan kurungan. ${ }^{17}$

Dari tuntutan tersebut hakim memutuskan pidana penjara 5 (lima) bulan dan denda sebesar Rp. 12.000.000,- (dua belas juta rupiah) dengan ketentuan apabila tidak dibayar diganti dengan pidana kurungan selama 6 (enam) bulan. Hal-hal yang menjadi pertimbangan hakim sebagai berikut:

Hal-hal yang memberatkan: Bahwa perbuatan terdakwa tidak menjadi contoh yang baik dalam mengendarai kendaraan roda empat di jalan tol.

Hal-hal yang meringankan:

1. Bahwa terdakwa berlaku sopan dan tidak mempersulit jalannya persidangan.

2. Bahwa terdakwa masih berusia muda dan masih berstatus mahasiswa.

3. Bahwa terdakwa maupun keluarga terdakwa telah meminta maaf kepada keluarga korban.

Putusan hakim tersebut dirasa penulis kurang tepat, karena tidak memenuhi tujuan hukum itu sendiri, yaitu keadilan, kemanfaatan, dan kepastian hukum, karena

17 Lampiran 1 : Tuntutan Pidana Putusan Pengadilan Negeri Jakarta Nomor : 151/Pid.Sus/2013/PN.Jkt. Tim. Hlm.2 
pemidaan yang dilakukan hanya bersifat formalitas saja, tujuan dari pemidanaan untuk memberikan efek jera tidak dapat diterapkan serta menimbulkan stigma bahwa keadilan dapat dibeli dengan materi dan kekuasaan, karena berat ringannya pidana dapat ditawar dengan uang.

Kasus lainnya yang serupa yaitu pada Putusan Nomor : 215/Pid.B/2010/PN.SKH. Terdakwa Handoko (24 tahun) didakwa mengendarai mobil karena kelalaiannya menyebabkan orang lain meninggal dunia 4 (empat) orang, dan korban luka berat 2 (dua) orang dan korban luka ringan 2 (dua) orang. Handoko dituntut telah melanggar Pasal 310 ayat (4) dan Pasal 310 ayat (3) dan Pasal 310 ayat (2), serta dituntut dengan sanksi pidana penjara selama 1 (satu) tahun 6 (enam) bulan dikurangi selama terdakwa dalam masa tahanan. Serta Handoko tidak memiliki Surat Izin Mengemudi (SIM) sehingga yang dilakukan oleh terdakwa menyebabkan penderitaan dan kerugian bagi orang lain yang hakim rasa menjadi hal yang memberatkan sedangkan bantuan dari pihak keluarga untuk para korban dan karena terdakwa belum pernah dihukum maka menjadi pertimbangan hakim sebagai hal yang meringankan terdakwa. Akhirnya hakim memvonis penjara selama 2 (dua) tahun dan dikurangi masa tahanan terdakwa. ${ }^{18}$

Akibat perbuatan kecelakaan lalu lintas yang dilakukan M. Rasyid Amrullah Rajasa dengan Handoko sama beratnya, pada kedua perkara tersebut masing-masing terdakwa dengan keluarga korban melakukan pemufakatan dengan memberikan bantuan dan meminta permohonan maaf. Tetapi putusan yang dilakukan hakim dirasa tidak adil bagi masyarakat karena pidana penjara yang didapatkan Handoko lebih lama daripada M. Rasyid padahal akibat perbuatan mereka sama beratnya. Sehingga tujuan hukum yakni kemanfaatan tidak terpenuhi. Kemanfaatan hukum harus didapatkan oleh semua pihak tidak hanya pihak yang berperkara saja, maka dari itu putusan hakim untuk M. Rasyid dirasa kurang berat oleh masyarakat, karena jika dendanya saja yang besar maka M. Rasyid jelas bisa memenuhinya karena ia anak seorang menteri, sedangkan Handoko hanya masyarakat biasa apalagi pemidanaan memiliki tujuan untuk memberikan efek jera.

\section{Analisis Diskriminasi Hukum}

Peristiwa ketidak adilan dalam penegakan hukum ini dapat dikaji dengan teori milik Donald Black. Sosiologi hukum memperlihatkan banyaknya unsur-unsur dari luar hukum yang menguasai kegiatan hukum tentang bagaimana membentuk dan melaksanakan hukum tersebut. Sosiologi hukum mengutamakan pada pelaksanaan hukum yang secara pantas dan patut, yaitu dengan memahami aturan hukum sebagai sarana atau alat bagi aparat penegak hukum dalam menegakkan hukum.

Salah satu teori sosiologi hukum yang tepat untuk melihat adanya kerjasama antara penegak hukum dengan elit lokal yaitu teori Perilaku Hukum (behavior of law) yang dikenalkan oleh Donald Black. Dalam teori ini memperkenalkan aspek variabel atau indikator atau faktor-faktor sosial yang mempengaruhi adanya diskriminasi hukum.

Pertama, stratifikasi sosial yaitu aspek vertikal dari kehidupan sosial yang sesuai dengan kedudukan sosial ekonomi atau peringkat sosial. Stratifikasi sosial yaitu pelapisan atau penjenjangan yang ada dalam kehidupan masyarakat karena adanya perbedaan status, kekuasaan, keturunan, dan lain-lain.

18 Lampiran 4 : Putusan Pengadilan Negeri Sukoharjo Nomor : 215/Pid.B/2010/PN.SKH. hlm.2, 31-34 
Menurut Aristoteles, masyarakat dapat diklasifikasikan menjadi tiga kategori, yaitu sangat kaya, sangat miskin, dan golongan yang berada diantara mereka. Sedangkan menurut Karl Marx stratifikasi sosial terdiri dari golongan proletariat, kapitalis (borjuis) dan menengah (borjuis rendah).

Penyebab terjadinya stratifikasi menurut Paul B Horton dan Chester L. Hunt adalah:

a. Kekayaan dan Penghasilan, tingkatan seseorang tidak dapat langsung sama dengan penghasilannya. Namun uang dapat menjadi unsur pembeda tingkatan sosial yang penting karena perannya besar dalam mendiskripsikan latar belakang kehidupan seseorang.

b. Pekerjaan adalah faktor sosial yang penting sebagai suatu indikator untuk melihat kelas sosial seseorang karena banyak aspek kehidupan yang berhubungan dengan pekerjaan.

c. Pendidikan mempengaruhi terjadinya stratifikasi sosial karena pendidikan yang tinggi pasti dilihat orang yang memiliki uang dan motivasi yang tinggi. Pendidikan dapat merubah cara hidup seseorang, baik dalam berpikir maupun bertindak. ${ }^{19}$

Law Varies Directly with Rank adalah dalil dengan arti bahwa manusia yang bertingkat tinggi memiliki hukum lebih banyak daripada manusia yang bertingkat rendah. Dalil Downward Law is Greater Than Upward Law memiliki makna bahwa hukum memiliki beraneka macam wujud, bisa berupa undang-undang, larangan, dan perintah. Sedangkan pelaporan, penahanan, penuntutan dan penghukuman lebih ditujukan kepada masyarakat yang bertingkat rendah.

Putusan hakim dalam kasus M. Rasyid Amrullah Rajasa dan Handoko sangatlah berbeda. Walaupun keduanya dituntut dengan pasal yang sama dan dengan kasus yang serupa. Tetapi hakim dengan pandangan yang berbeda melalukan ketidak adilan dalam memutus kasus mereka. Apabila dilihat dari teori Donald Black, maka bisa dilihat adanya perbedaan stratifikasi sosial antara M. Rasyid dan Handoko.

M. Rasyid Amrullah Rajasa merupakan anak seorang Menteri Koordinatir Perekonomian, Hatta Rajasa pada masa itu. Tentu M. Rasyid memiliki kekuasaan dan uang untuk dapat meminta keringanan dalam sanksi pidananya. Selain itu M. Rasyid pada masa itu masih menjadi mahasiswa di perguruan tinggi di London, Kerajaan Inggris dengan status mahasiswa semester akhir, maka tentu M. Rasyid adalah anak dari kalangan keluarga mampu atau kaya. Sedangkan Handoko hanyalah masyarakat biasa yang tidak mempunyai kekuasaan atau materi untuk dapat meminta keringanan atas sanksi yang diberikan kepadanya.

Kedua, morfologi yaitu aspek horizontal dalam masyarakat karena adanya perbedaan profesi, keakraban atau intimasi dan integrasi. The Relationship between Law and Differentiation is Curvelinear yaitu manusia yang memperoleh lebih banyak perbedaan dalam lapisan sosial maka jumlah hukum semakin banyak begitu pun sebaliknya. Contohnya adalah kasus kontrak jenisnya lebih banyak terjadi kepada masyarakat dengan variasi morfologi tinggi daripada masyarakat morfologi rendah.

19 Soerjono Soekanto, Sosiologi Suatu Pengantar. (Jakarta: PT Raja Grafindo Persada, 2007) hlm. 263. 
The Relationship between Law and Relational Distance Curvilinear yaitu hukum tidak berlaku bagi masyarakat yang memiliki hubungan dekat. Jadi hukum semakin banyak atau bertumbuh bersamaan dengan adanya jarak atau kerenggangan. Law Varies Directly with Integration yaitu masyarat yang ada pada lingkaran pusat sosial lebih memiliki hukum daripada masyarakat yang ada pada lingkaran luar sosial (marginal). Contohnya adalah perselisihan antara masyarakat elit cenderung sampai ke polisi atau pengadilan daripada perselisihan antara masyarakat penganggur atau gelandangan (marginal).

Dalam kasus M. Rasyid, karena orang tuanya seorang menteri maka ia memiliki kekuasaan untuk kenal dengan para petinggi penegak hukum. Dengan adanya hubungan yang kenal atau dekat ini maka M. Rasyid dapat meminta keringanan kepada penegak hukum atas sanksi yang ia akan dapatkan. M. Rasyid termasuk dalam golongan masyarakat yang berada pada pusat lingkaran sosial, maka memiliki hukum lebih banyak daripada Handoko yang hanya seorang masyarakat biasa.

Ketiga, kultur atau budaya yaitu aspek simbolik, seperti apa yang baik dan buruk (religi), termasuk karya dan folklor. Law Varies Directly with Culture yaitu masyarakat yang tingkat kebudayaannya tinggi lebih banyak memiliki hukum. Contohnya suku nomaden tidak memiliki hukum sebanyak masyarakat yang memiliki kebudayaan tinggi. Law is Greater in a Direction Toward Less Conventionality than More Conventionality yaitu kejahatan yang dikerjakan oleh masyarakat kalangan minoritas dan korbannya dari kalangan mayoritas, oleh karena itu hukumannya akan lebih berat begitu pun sebaliknya. Contohnya yaitu pelaku kejahatan orang berkulit hitam lalu korban orang kulit putih.

Law is Greater Toward Less Culture than Toward More Culture yaitu memiliki makna kejahatan yang dilakukan oleh orang yang tidak berbudaya atau berpendidikan rendah terhadap orang yang berbudaya atau berpendidikan tinggi maka hukuman yang didapatkan akan lebih berat dibandingkan pelaku adalah orang yang berpendidikan tinggi terhadap orang yang tidak berpendidikan atau berpendidikan rendah. Centrifugal Law is Greater than Centripetal Law yaitu memiliki makna bahwa tindak pidana yang dilakukan oleh seorang marginal atau pengangguran terhadap orang yang dalam lingkaran pusat sosial atau berkedudukan terpandang maka akan mendapatkan hukuman yang berat, begitu pun sebaliknya.

Diketahui bahwa M. Rasyid Amrullah Rajasa adalah seorang mahasiswa perguruan tinggi di London, maka M. Rasyid berasal dari keluarga atau lingkungan yang berkebudayaan atau berpendidikan tinggi, maka diberikan perlakuan yang berbeda ditambah dengan $\mathrm{M}$. Rasyid memiliki ayah seorang menteri. Berbeda dengan Handoko yang hanya masyarakat biasa dengan tingkat pendidikan yang standar maka M. Rasyid bisa mendapatkan keringanan hukuman daripada Handoko yang pasti akan mendapatkan hukuman yang lebih berat.

Keempat, struktur organisasi atau perilaku hukum yang dipengaruhi oleh organisasi. Organisasi yang dimaksud adalah negara, pemerintahan, perusahaan, partai politik, dan lembaga-lembaga lain. Law Varies Directly with Organization yaitu semakin banyak intervensi atau campur tangan negara terhadap masyarakat maka semakin banyak pula hukum. Law is Greater in Direction Toward Less Organization than Toward More 
Organization yaitu memiliki makna hukum lebih mengarah kepada manusia daripada organisasi, lebih banyak organisasi yang melaporkan individu kepada polisi daripada individu yang melaporkan organisasi ke polisi, serta organisasi lebih sering menang dalam sebuah kasus daripada individu.

Dalam kasus M. Rasyid dapat dikatakan adanya campur tangan dari pemerintah atau lembaga-lembaga lain yang tidak lain adalah lembaga dimana tempat ayahnya bekerja atau memiliki kekuasaan.

Kelima, pengendalian sosial (Social control) yaitu aspek normatif dari kehidupan sosial. Hal-hal yang dapat mengendalikan perilaku menyimpang, seperti adanya larangan, dakwaan, dan pemidanaan. Law Varies Inversely with Other Social Control yaitu jika control sosial kuat maka kontrol hukum melemah begitu pun sebaliknya. Law Varies Directly with Respectability yaitu memiliki makna hukum lebih banyak ditemukan pada golongan masyarakat terhormat daripada masyarakat yang tidak terhormat, seperti penjahat, gelandangan. Law is Greater in a Direction Toward Less Respectability than Toward More Respectability yaitu masyarakat yang tidak terhormat lebih banyak dijadikan untuk tujuan hukum dan cenderung tidak mendapatkan manfaat dari hukum itu sendiri.

Sebuah peraturan atau undang-undang dibentuk agar masyarakat yang hidup disebuah negara memiliki rasa aman, serta dapat hidup dengan damai dan tertib. Oleh karena itu undang-undang haruslah ditaati agar tercapainya tujuan dari pembentukan undang-undang itu sendiri.

Secara nyata hukum adalah seperangkat prinsip dan pedoman yang mengatur korelasi antara manuia dalam kehidupan bersama, baik dalam wujud kekerabatan, kekeluargaan, di dalam suatu lingkungan. Masyarakat hukum mengatur kehidupannya sendiri berdasarkan nilai dan norma dalam kehidupan masyarakat itu sendiri atau yang sama-sama memiliki tujuan tertentu.

\section{Kesimpulan}

Dari kasus M. Rasyid Amrullah Rajasa dengan Handoko dapat dilihat adanya diskriminasi dalam penegakan hukum yang diberikan hakim kepada kedua terdakwa. M. Rasyid dengan Handoko dituntut dengan dakwaan yang sama yaitu mengendarai mobil yang karena kelalaiannya menyebabkan orang lain meninggal dunia dengan Pasal 310 ayat (4) Undang-Undang No. 22 Tahun 2009 tentang Lalu Lintas dan Angkutan Jalan serta karena kelalaiannya menyebabkan kecelakaan lalu lintas dengan korban luka ringan dan kerusakan kendaraan dan/atau barang sesuai dengan dakwaan Pasal 310 ayat (2) UndangUndang No. 22 Tahun 2009 tentang Lalu Lintas dan Angkutan Jalan. Dalam putusan hakim mereka dikenakan sanksi yang berbeda, padahal akibat perbuatannya sama beratnya.

Putusan M. Rasyid adalah pidana penjara 5 (lima) bulan dan denda sebesar Rp. 12.000.000,- (dua belas juta rupiah) dengan ketentuan apabila tidak dibayar diganti dengan pidana kurungan selama 6 (enam) bulan. Sedangkan Handoko divonis penjara selama 2 (dua) tahun dan dikurangi masa tahanan.

Dilihat dari teori diskriminasi hukum yaitu Teori Perilaku Hukum (behavior of law) yang diperkenalkan oleh Donald Black, dalam teori ini terdapat unsur-unsur sosial yang dapat menguasai adanya diskriminasi hukum: 


\section{Stratifikasi Sosial}

M. Rasyid Amrullah Rajasa merupakan anak seorang Menteri Koordinatir Perekonomian, Hatta Rajasa pada masa itu. Tentu M. Rasyid memiliki kekuasaan dan uang untuk dapat meminta keringanan dalam sanksi pidananya. Selain itu M. Rasyid pada masa itu masih menjadi mahasiswa di perguruan tinggi di London, Kerajaan Inggris dengan status mahasiswa semester akhir, maka tentu M. Rasyid adalah anak dari kalangan keluarga mampu atau kaya. Sedangkan Handoko hanyalah masyarakat biasa yang tidak mempunyai kekuasaan atau materi untuk dapat meminta keringanan atas sanksi yang diberikan kepadanya.

2. Morfologi

Dalam kasus M. Rasyid, karena orang tuanya seorang menteri maka ia memiliki kekuasaan untuk kenal dengan para petinggi penegak hukum. Dengan adanya hubungan yang kenal atau dekat ini maka M. Rasyid dapat meminta keringanan kepada penegak hukum atas sanksi yang ia akan dapatkan. M. Rasyid termasuk dalam golongan masyarakat yang berada pada pusat lingkaran sosial, maka memiliki hukum lebih banyak daripada Handoko yang hanya seorang masyarakat biasa.

3. Kultur atau Budaya

Diketahui bahwa M. Rasyid Amrullah Rajasa merupakan seorang mahasiswa dari perguruan tinggi di London, maka M. Rasyid berasal dari keluarga atau lingkungan yang berkebudayaan atau berpendidikan tinggi, maka diberikan perlakuan yang berbeda ditambah dengan $\mathrm{M}$. Rasyid memiliki ayah seorang menteri. Berbeda dengan Handoko yang hanya masyarakat biasa dengan tingkat pendidikan yang standar maka M. Rasyid bisa mendapatkan keringanan hukuman daripada Handoko yang pasti akan mendapatkan hukuman yang lebih berat.

4. Struktur Organisasi

Dalam kasus M. Rasyid dapat dikatakan adanya campur tangan dari pemerintah atau lembaga-lembaga lain yang tidak lain adalah lembaga dimana tempat ayahnya bekerja atau memiliki kekuasaan.

5. Pengendalian Sosial

Sebuah peraturan atau undang-undang dibentuk agar masyarakat yang hidup disebuah negara memiliki rasa aman, serta dapat hidup dengan damai dan tertib. Oleh karena itu undang-undang haruslah ditaati agar tercapainya tujuan dari pembentukan undang-undang itu sendiri.

Dari uraian di atas maka kasus M. Rasyid Amrullah Rajasa dan Handoko benar merupakan kasus yang mengalami diskriminasi dalam penegakan hukum. Saran untuk para aparat penegak hukum adalah dalam menegakkan hukum sebaiknya menjunjung tinggi nilai keadilan dan menggunakan hati nurani agar tidak terjadi tebang pilih atau membedabedakan dalam mengadili suatu perkara, karena hak semua warga negara adalah sama, yaitu sama-sama harus mendapatkan keadilan. 


\section{Daftar Pustaka}

\section{Buku}

Bagir Manan, Penegakan Hukum yang Berkeadilan, (Jakarta: Varia Peradilan No. 241, 2005).

Peter M. Marzuki, Penelitian Hukum. (Jakarta: Prenadamedia Group, 2005).

Ramli Hutabarat, Persamaan di Hadapan Hukum, (Jakarta: Ghalia Indonesi, 1995)

Roscoe Pound, Pengantar Filsafat Hukum, (Jakarta: Brahtara 1989).

Satjipto Rahardjo dan Anton Tabah. Polisi, Pelaku dan Pemikir. (Jakarta: Gramedia Pustaka Utama., 1993) hlm. 146.

Publishing 2009)

Penegakan Hukum, Suatu Tinjauan Sosiologis, (Yogyakarta: Genta

, Pendidikan Hukum Sebagai Pendidikan Manusia, (Yogyakarta: Genta Publishing 2009)

Soerjono Soekanto , Sosiologi Suatu Pengantar. (Jakarta: PT Raja Grafindo Persada, 2007) hlm. 263.

Soeroso, Pengantar Ilmu Hukum, Cetakan Ketiga Belas, (Jakarta: Sinar Grafika, 2013)

Sudikno Mertokusumo, Mengenal Hukum Suatu Pengantar, (Yogyakarta: Liberty (2006)

\section{Artikel dalam Jurnal}

Ana Suheri, "Wujud Keadilan dalam Masyarakat di Tinjau dari Perspektif Hukum Nasional", Jurnal Morality, Vol. 4 No. 1 (2018): 60-68

Asep H. Suparman, "Penegakan Hukum terhadap Penyelenggaraan Pelayanan Publik" Jurnal Wawasan Yuridika, Vol. 29 No. 2 (2013): 849-853

Bahder Johan Nasution, "Kajian Filosofis tentang Konsep Keadilan dari Pemikiran Klasik Sampai Pemikiran Modern” Yustisia, Vol. 3 No. 2 (2014): 119-130

Damanhuri Fattah, “Teori Keadilan Menurut John Rawls" Jurnal TAPIs, Vol. 9 No. 2 (2013): $31-45$

Hasaziduhu Moho, "Penegakan Hukum di Indonesia Menurut Aspek Kepastian Hukum, Keadilan, dan Kemanfaatan" Jurnal Warta, Edisi 59 (2019)

Hayat, "Keadilan sebagai Prinsip Negara Hukum: Tinjauan Teoretis dalam Konsep Demokrasi”, Padjadjaran Jurnal Ilmu Hukum, Vol. 2 No. 2 (2015): 388-408

Husein M. Maruapey, "Penegakan Hukum dan Perlindungan Negara (Analisys Kritis terhadap Kasus Penistaan Agama Oleh Patahana Gubernur DKI Jakarta)" Jurnal Ilmu Politik dan Komunikasi, Vol. 7 No. 1 (2017): 21-30

Ismail Shaleh Rusli, "Prasangka Menimbulkan Penurunan Tingkat Kepercayaan Masyarakat Terhadap Penegak Hukum", Indonesia yang Berkeadilan Sosial tanpa Diskriminasi, (2016): 239-245, hlm. 244 
Ismansyah dan Andreas Ronaldo, "Efektivitas Pelaksanaan Hukum dalam Menyelesaikan Konflik sosial Untuk Mewujudkan Keadilan”, Jurnal Delicti, Vol. 11 No. 3 (2013)

Jupri dan Roy Marthen Moonti, "Diskriminasi Hukum dalam Pemberantasan Korupsi Politik di Daerah”, Dialogia Iuridica, Vol. 11 No. 1 (2019): 114-131

Koerniatmanto Soetoprawiro, "Keadilan sebagai Keadilan” Jurnal Hukum Pro Justitia, Vol. 28 No. 2 (2010): 229-256

Laurensius Arliman S., "Mewujudkan Penegakan Hukum yang Baik di Negara Hukum Indonesia" Dialogia Iuridica, Vol. 11 No. 1 (2019): 001-020

Marliang, “Menimbang Paradigma Keadilan Hukum Progresif”, Jurnal Konstitusi, Vol. 14 No. 2 (2017): 316-331

Nuno Saldanha Da Silva Fatima, Karolus Kopong Medan, dan Saryono Yohanes, "Diskriminasi Penegakan Hukum Dalam Penanganan Pencurian Arus Listrik Di Distrik Dili” Jurnal Magister Hukum Udayana, Vol. 6 No. 2 (2017): 237-247

Ridwan, "Menciptakan Keadilan dengan Penerapan Hukum Progresif Melalui Pendekatan Ilmu Kehutanan", Kanun Jurnal Ilmu Hukum, No. 57 Th. 14 (2012): 249-262

Rosdalina Bukido, "Paradigm and Reality of Law Enforcement in Indonesia"

Sanyoto, "Penegakan Hukum di Indonesia", Jurnal Dinamika Hukum, Vol. 8 No. 3 (2008): 200-204

Satjipto Rahardjo, "Hukum Untuk Manusia, Bukan Manusia Untuk Hukum” Jurnal Ultimatum, Edisi 2 (2008)

Soejadi, H.R., "Refleksi Mengenai Hukum dan Keadilan, Aktualisasinya di Indonesia", Jurnal Ketahanan Nasional, Vol. 8 No. 2 (2003): 1-18

Tonny Rompis, "Kajian Sosiologi Hukum Tentang Menurunnya Kepercayaan Masyarakat Terhadap Hukum Dan Aparat Penegak Hukum Di Sulawesi Utara”, Lex Crimen, Vol. 4 No. 8 (2015): 166-176

Ucuk Agiyanto, "Penegakan Hukum di Indonesia: Eksplorasi Konsep Keadilan Berdimensi Ketuhanan" Hukum Ransendental, 493-503

Umar Sholahudin, "Membangun Keadilan Restoratif Bagi Si Miskin”, Sejarah Dan Budaya, Tahun Ketujuh, No. 1, (2013): 34-50, hlm.34

Yohanes Suhardin, "Fenomena Mengabaikan Keadilan dalam Penegakan Hukum", Mimbar Hukum, Vol. 21 No. 2 (2009): 203-408

Zainab Ompu Jainah, "Penegakan Hukum dalam Masyarakat", Journal of Rural and Development, Vol.3 No. 2 (2012): 165-172

Zainuddin Ali, "Penegakan Hukum sebagai Peluang Menciptakan Keadilan", Jurnal Jurisprudence, Vol. 2 No. 1 (2015) 
Zakki Adlhiyati dan Achmad, "Melacak Keadilan dalam Regulasi Poligami: Kajian Filsafat Keadilan Aristoteles, Thomas Aquinas, dan John Rawls", Undang: Jurnal Hukum, Vol. 2 No. 2 (2019): 409-431

\section{Peraturan Perundang-undangan}

Undang-Undang Republik Indonesia Nomor 39 Tahun 1999 tentang Hak Asasi Manusia.

Undang-Undang No. 22 Tahun 2009 tentang Lalu Lintas dan Angkutan Jalan.

Undang-Undang Nomor 2 Tahun 1986 Tentang Peradilan Umum Jo Undang-Undang Nomor 8 Tahun 2004 Tentang Perubahan Undang-Undang Nomor 2 Tahun 1986 Tentang Peradilan Umum

Undang-Undang Dasar Negara Republik Indonesia Tahun 1945

Lampiran 1 : Tuntutan Pidana Putusan Pengadilan Negeri Jakarta Nomor : 151/Pid.Sus/2013/ PN.Jkt. Tim. Hlm.2

Lampiran 4 : Putusan Pengadilan Negeri Sukoharjo Nomor : 215/Pid.B/2010/PN.SKH. hlm.2, $31-34$

\section{Websites}

Andylala Waluyo, "Putra Menko Hatta Rajasa Dapat Vonis 5 Bulan Penjara" 25 Maret 2013, https:/www.voaindonesia.com/a/putra-menko-hatta-rajasa-divonis-lima-bulanpenjara/1628028.html, diakses pada 29 Desember 2020

Fabian Januarius Kuwado, “Akhir Kisah Kecelakaan Anak Sang Menteri” 26 Maret 2013, https://megapolitan.kompas.com/read/2013/03/26/11124620/Akhir.Kisah.Kecelakaan. Sang.Anak.Menteri?page=all, diakses pada 28 Desember 2020

Kristanto Purnomo, "Kejanggalan dan Keanehan dalam Peristiwa Kecelakaan Anak Hatta Rajasa” 2 Januari 2013, https://www.tribunnews.com/nasional/2013/01/02/kejanggalandan-keanehan-dalam-peristiwa-kecelakaan-anak-hatta-rajasa, diakses pada 28 Desember 2020

Sandro Gatra, "Putusan Rasyid Rajasa Usik Rasa Keadilan" 26 Maret 2013, https://megapolitan. kompas.com/read/2013/03/26/12184248/Putusan.Rasyid.Rajasa.Usik.Rasa.Keadilan, diakses pada 28 Desember 2020 